Власова Ю.А. ${ }^{1}$, Абрамова А.И. ${ }^{1}$

${ }^{1}$ Российский экономический университет им. Г.В. Плеханова

\title{
Проблемы укрепления доходного потенциала региональных бюджетов в России на примере Калужской области
}

\section{АННОТАЦИЯ:}

Статья посвящена изучению особенностей формирования доходов российских регионов на примере Калужской области. Предметом исследования является социально-экономическое и финансовое положение Калужской области.

Целью работы является выявление возможных социально-экономических и бюджетных рисков субъекта, влияющих на доходный потенциал региона. А также выявление дополнительных резервов для повышения доходной части бюджет субъекта.

В работе раскрыты наиболее актуальные проблемы покрытия расходов и управления долгом, проведена оценка бюджетного потенциала региона с помощью методов статистического анализа, а также посредством расчета показателей эффективности бюджетной политики.

Изучен доходный потенциал региона в части налоговых доходов как основного источника формирования бюджета региона. Оценены изменения в расходной части бюджета. Изучена долговая нагрузка субъекта и риски, связанные с изменением объема и структуры долга, а также методы управления государственным долгом.

Авторами предложены рекомендации, направленные на повышение доходного потенциала региона с учетом его особенностей и текущей экономической ситуации, которые могли бы быть использованы при разработке бюджетной политики субъекта.

Доходный потенциал регионов находится в сложном положении, поэтому субъектам следует мобилизовать все свои силы на его укрепление. В свете риска снижения доходов от налоговых поступлений требуется развивать малое и среднее предпринимательство, которое обеспечивало бы население необходимыми продуктами и услугами и создавало рабочие места. Для этого необходимо активнее внедрять государственно-частное партнерство, максимально облегчать ведение бизнеса путем введения налоговых льгот и ускорения и упрощения бюрократических процедур. Также нужно снижать долю непроизводительных расходов и наращивать производительные, что приведет к повышению эффективности бюджетной политики региона. Комплексное решение данного вопроса в настоящее время приведет к мощному положительному эффекту для всей экономики региона в долгосрочном периоде.

КЛЮЧЕВЫЕ СЛОВА: доходный потенциал, бюджет субъекта, риски бюджета, налоговые доходы

JEL: H12, H20, H71, R11

ДЛЯ ЦИТИРОВАНИЯ:

Власова, Ю.А., Абрамова, А.И. (2015). Проблемы укрепления доходного потенциала региональных бюджетов в России на примере Калужской области. Креативная экономика, 9(10), 1255-1276. doi: 10.18334/ce.9.10.1964

Власова Юлия Ашумовна, канд. экон.наук, ст. преподаватель кафедры финансов и цен, Российский экономический университет им. Г.В. Плеханова (ја.vlasova@mail.ru)

Абрамова Анастасия Игоревна, студентка 4 курса финансового факультета, Российский экономический университет им. Г.В. Плеханова

ПОСТУПИЛО В РЕДАКЦИЮ: 02.10.2015 / ОПУБЛИКОВАНО: 30.10.2015 ОТКРЫТЫЙ ДОСТУП: http://dx.doi.org/10.18334/ce.9.10.1964

(с) Власова, Ю.А., Абрамова, А.И. / Публикация: ООО Издательство

"Креативная экономика"

Статья распространяется по лицензии Creative Commons CC BY-NC-ND

(http://creativecommons.org/licenses/by-nc-nd/3.0/)

ЯЗЫК ПУБЛИКАЦИИ: русский 


\section{Введение}

В настоящее время проблема укрепления доходного потенциала региональных бюджетов остается одной из наиболее актуальных проблем российской экономики. По оценкам экспертов Высшей школы экономики, в настоящее время 20 регионов находится на грани дефолта ${ }^{1}$. В связи с ухудшением экономической ситуации возникли новые риски ухудшения социально-экономического развития, что приводит к возникновению рисков для бюджетов регионов. Эти проблемы затронут или уже затронули не только «проблемные», отстающие регионы, но и успешно развивающиеся. Так, интересен пример Калужской области, одного из самых динамично развивающихся субъектов Российской Федерации. Данный регион, расположенный в Центральном федеральном округе, отличается выгодным географическим положением и занимает ведущее место в рейтинге инвестиционного климата регионов России.

Калужская область является промышленно-ориентированным регионом. Ведущее место в структуре хозяйственного комплекса Калужской области занимает промышленное производство. Чуть менее половины приходится на машиностроение и металлообработку (41,9\%), далее идут пищевая промышленность $(23,4 \%)$ и лесная, деревообрабатывающая и целлюлозно-бумажная промышленность $(11,4 \%)$. Согласно исследованиям экспертов (Валентей, Бахтизин, Бухвальд, Кольчугина, 2014) уже после кризиса 2009-2010 гг. регион входил в пятерку субъектов, имеющих высокие перспективы роста. Регион ежегодно демонстрировал стабильно положительные темпы роста основных социально-экономических показателей.

В этой связи особенно интересным представляется изучение степени влияния текущей нестабильной экономической ситуации на экономическое положение области.

В работе будут рассмотрены как социально-экономические показатели региона (Репова, Сазанова, Лобанова, 2014), так и индикаторы, отражающие эффективность бюджетной политики субъекта, с целью выявления возможных рисков устойчивости бюджета региона.

\footnotetext{
${ }^{1}$ зубаревич, Н.В., Горина, Е.А. (2015). Социальные расходы в России: федеральные и региональные бюджеты (Вып. 3). М.: НИУ ВШЭ.
} 


\section{Анализ рисков в области социально-экономического развития}

Почти $40 \%$ валовой добавленной стоимости, по данным Федеральной службы государственной статистики Калужской области, приходится на обрабатывающие производства (максимальный показатель по Центральному федеральному округу). Однако сложившиеся экономические условия: замедление экономического развития, девальвация рубля, рост инфляции, отток иностранного капитала и инвестиций, сокращение потребительского спроса, эмбарго на некоторые импортные товары, - крайне негативно отразились на развитии региона. Так, за первое полугодие 2015 года индекс производства по виду экономической деятельности «Обрабатывающие производства» составил $88,2 \% \quad$ к соответствующему периоду предыдущего года, хуже лишь в Москве, Московской и Тверской областях.

Уже с середины 2014 года наблюдалось снижение индекса промышленного производства (рис. 1). За первое полугодие 2015 года индекс составил 76,2\% к соответствующему месяцу предыдущего года (рис. 2).

Наблюдается существенное сокращение объема инвестиций в основной капитал (рис. 3), по всей видимости, связанное с оттоком инвестиций из отрасли машиностроения и сокращением выпуска автомобилей, предприятия по производству которых располагаются в регионе, а также сокращения потребительской активности населения в 2015 г.

Тем не менее, следует предположить, что данная понижательная тенденция наблюдается в основном за счет проблем в машиностроительных и отдельных обрабатывающих отраслях, так как в сфере строительства за аналогичный период отмечается существенный рост $(119,0 \%)$ к уровню соответствующего периода 2014 года), также и в отраслях сельского хозяйства, по данным Росстата, производство скота и птицы на убой (в живом весе) за январь-июнь 2015 г., по сравнению с соответствующим периодом 2014 г., увеличилось на 1,2\%, молока - на $12,1 \%$, яиц - на 5,5\%. 


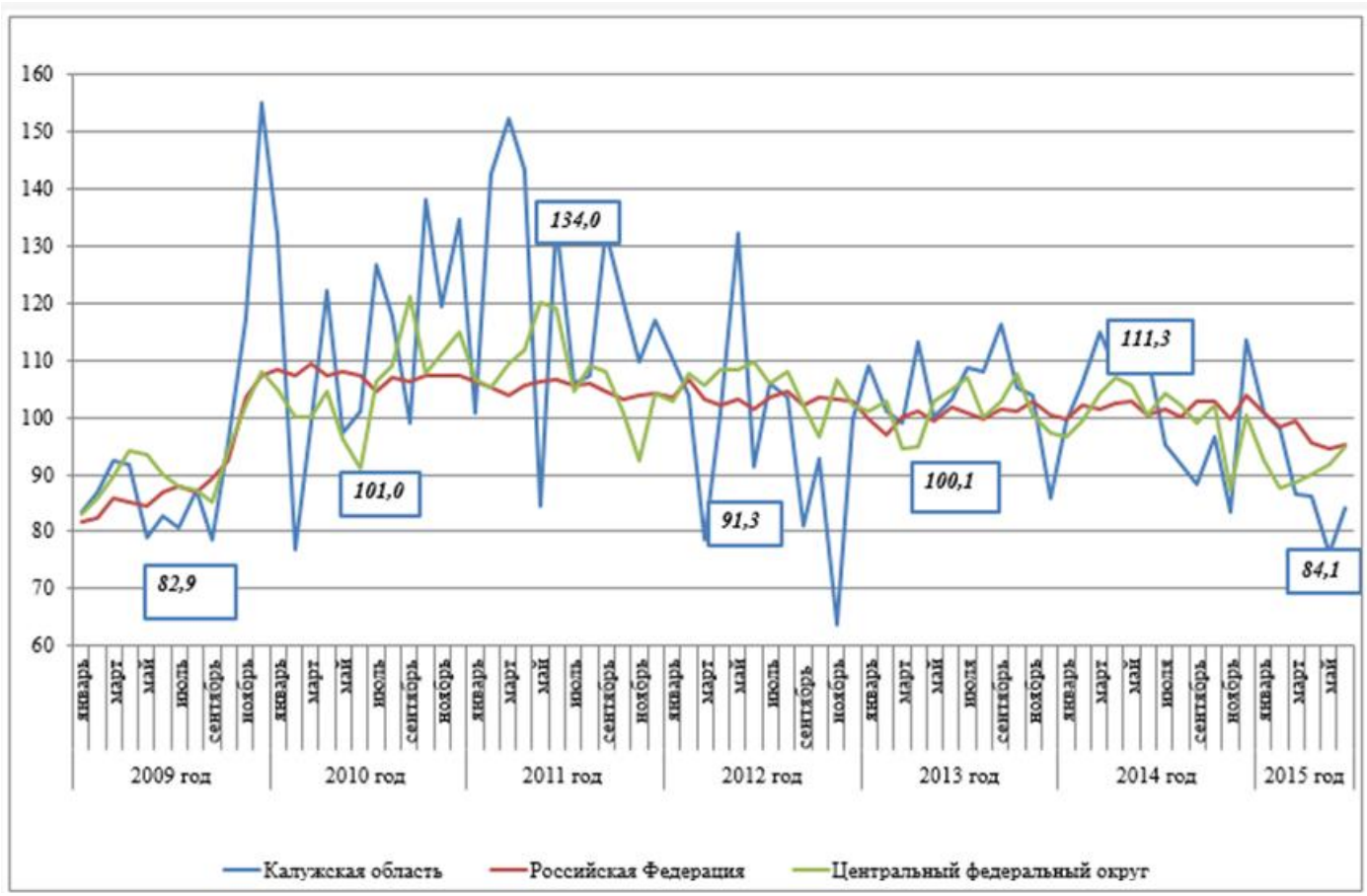

Рисунок 1. Динамика индекса промышленного производства к соответствующему месяцу предыдущего года, \% Источник: составлено авторами по данным Федеральной службы государственной статистики

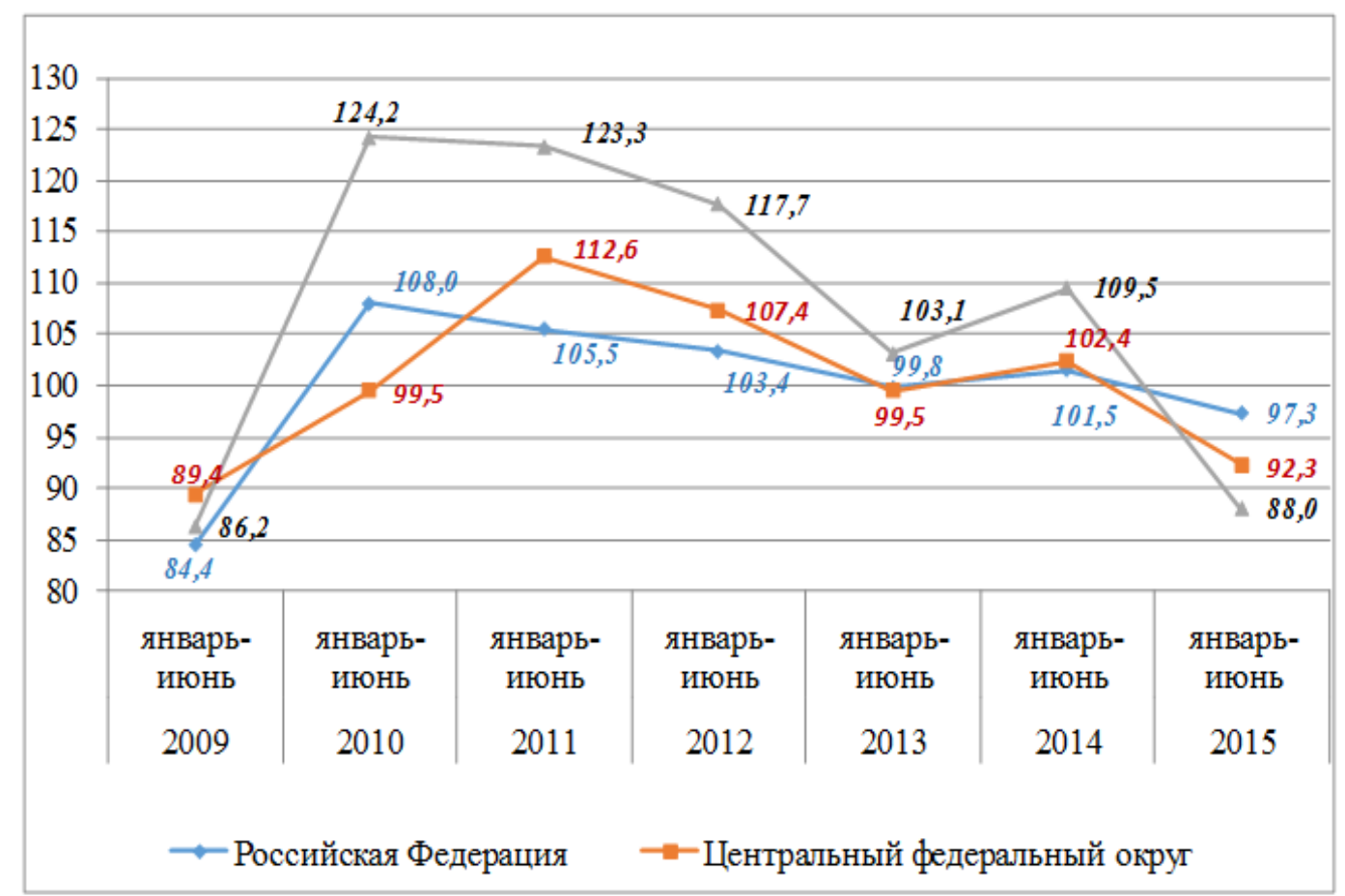

Рисунок 2. Динамика индекса промышленного производства к соответствующему месяцу предыдущего года, \% Источник: составлено авторами по данным Федеральной службы государственной статистики 


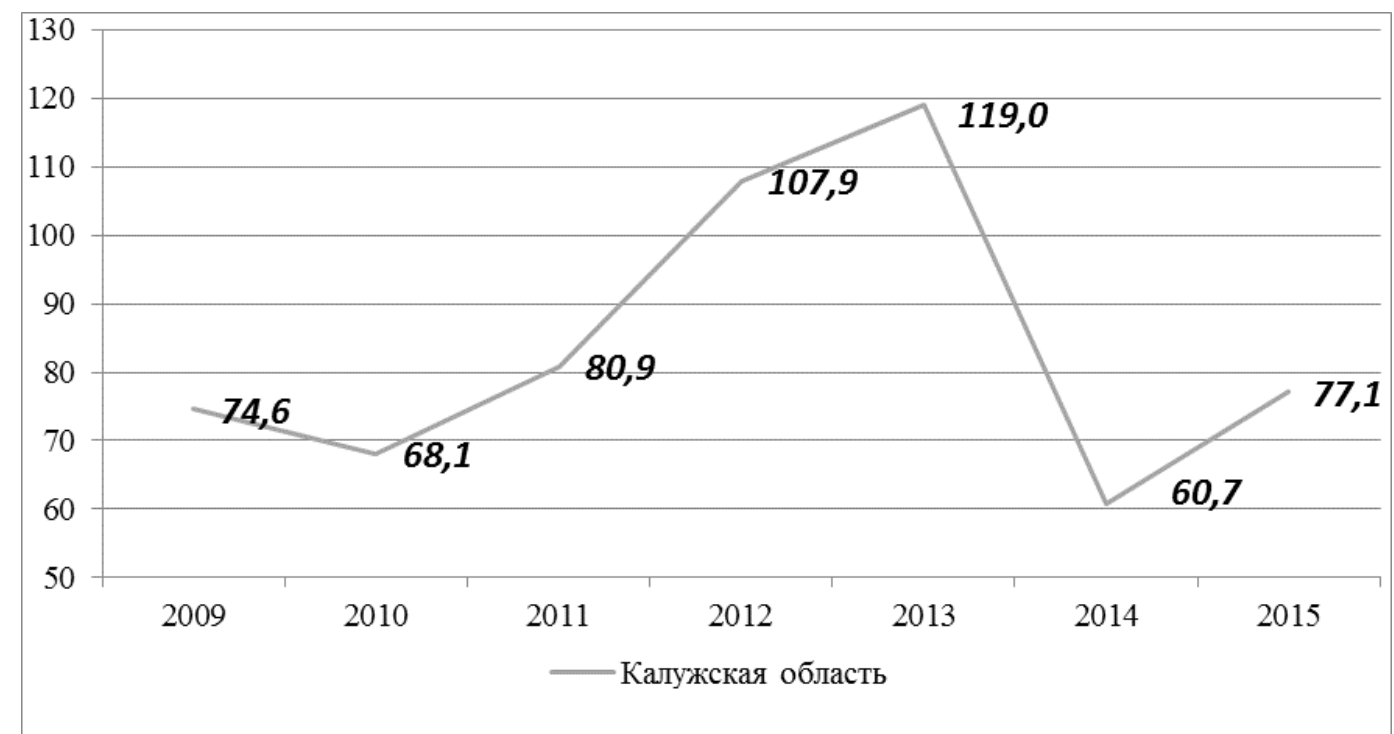

Рисунок 3. Индекс физического объема инвестиций в основной капитал Калужской области, июль к июлю, \%

Источник: составлено авторами по данным Федеральной службы государственной статистики

\section{Предпринимательство}

Доля прибыльных компаний Калужской области остается на стабильном уровне уже более 3 лет. И, более того, с начала 2015 года выросла больше чем на 3 процентных пункта.

За первое полугодие 2015 года сальдированный финансовый результат предприятий оказался ниже аналогичного периода предыдущего года. Объем кредиторской задолженности организаций Калужской области возрос на 9\%. Объем просроченной задолженности возрос более значительно - на $28 \%$ (июнь к июню предыдущего года).

В 2014 году количество занятых в малом и среднем бизнесе (МСБ) в Калужской области возросло на 3,1 тыс. человек, что является положительным показателем для области, так как в основном по ЦФО данный показатель за исследуемый период отрицательный, и еще лишь в трех регионах ЦФО достигнут положительный результат в данной сфере. Численность субъектов предпринимательства в Калужской области за год увеличилась на 2\% и составляет сейчас 13063 предприятия и 29200 индивидуальных предпринимателей. В малом и среднем бизнесе занято почти 107000 жителей области ${ }^{2}$, это почти $10 \%$ от всего населения области. По данным аналитиков, Калужская область стала одним из

\footnotetext{
2 Отчет губернатора о результатах деятельности Правительства Калужской области в 2014 2. и задачах на текущий период (2015, 19 марта) // Официальный портал органов власти Калужской области.
} 
лидеров рейтинга регионов Центрального федерального округа по количеству ИП, занимая второе место по ЦФО, уступая лишь Белгородской области.

Однако в первом квартале 2015 года средняя численность работников в МСБ сократилась почти на 4\% по сравнению с первым кварталом 2014 года. Это связанно в первую очередь с временным сокращением количества работников и МСБ, периодом спада потребительского спроса, сокращения ассортимента продукции из-за санкций и резкой девальвации рубля в 2014 году.

Опасение вызывает существенное сокращение объемов кредитования предприятий реального сектора экономики - на 32\% за первые семь месяцев 2015 года. По данным исследования МСП банка, долги малого бизнеса в регионе растут быстрее среднего по России.

Тем не менее, надо полагать, что ряд мер, предпринимаемых Правительством РФ и руководителями регионов, позволит ускорить выход предприятий из кризисной ситуации.

К этим мерам относятся:

1. Поддержка малого и среднего предпринимательства корпорацией МСП, являющейся агентом Внешэкономбанка, с которой у Калужской области подписано соглашение о сотрудничестве.

2. Антикризисные меры и программа импортозамещения, в рамках которых предоставляются льготы предприятиям, осуществляющим импортозамещение, а также налоговые двухлетние каникулы для МСБ.

Объем финансирования мероприятий государственной поддержки МСБ за 2014 год вырос на 60\% и составил 524 млн рублей ${ }^{3}$.

Правительством Калужской области активно реализуются меры поддержки предпринимательства. Программа поддержки МСБ предполагает различные виды и формы поддержки ${ }^{4}$, в том числе финансовой (предоставление государственных и муниципальных гарантий по обязательствам предприятий МСБ). Также разработаны 10 различных видов субсидий, реализуемых в рамках долгосрочной целевой программы «Развитие малого и среднего предпринимательства и стимулирование инновационной деятельности в Калужской области на

\footnotetext{
${ }^{3}$ Отчет губернатора о результатах деятельности Правительства Калужской области в 2014 г. и задачах на текущий период (2015, 19 марта) // Официальный портал органов власти Калужской области.

${ }^{4}$ Там же.
} 
2013-2015 годы». В программу мероприятий включена также поддержка предприятий, осуществляющих внешнеэкономическую деятельность.

\section{Инфляция}

Индекс цен производителей промышленных товаров в Калужской области составил в июле 2015 года 112,5\% к декабрю предыдущего года, что является одним из самых высоких показателей роста цен по ЦФО и выше аналогичного показателя по РФ в целом.

После существенного роста в последнем квартале 2015 года индекс цен на реализованную сельскохозяйственную продукцию снизился (97,3\% к декабрю 2014 года), в то время как в целом по ЦФО зафиксирован рост. Индекс цен на продукцию инвестиционного назначения за январь-июль 2015 года незначительно снизился в сравнении с аналогичным показателем 2014 года.

\section{Занятость}

C учетом снижения численности экономически активного населения в 2014 году, в Калужской области было отмечено снижение уровня безработицы до 4,2\%. За май-июль этот показатель вырос незначительно (на 0,1 п.п.), что ниже среднего показателя по ЦФО без учета Москвы и Московской области.

\section{Активность и доходы населения}

Оборот розничной торговли за период январь-июль сократился до 90,7\% к соответствующему периоду 2014 г. Это ниже аналогичного показателя за 2009 и 2010 годы, что связано, прежде всего, с параллельным снижением реальных доходов населения. В июне 2015 г. реальные денежные доходы сократились аналогично показателю розничной торговли на $90,8 \%$.

Таким образом, к возникающим рискам социальноэкономического развития региона следует отнести недостаток денежных средств: инвестиций и кредитных ресурсов, снижение объёма производства машиностроительной продукции, в связи с чем возникает риск роста безработицы, а также могут возникнуть проблемы с возвратом ранее взятых кредитов.

В виду нестабильной внешней экономической конъюнктуры, сохранения двухсторонних санкций предприятия области будут пытаться наращивать производство частично за счет своих средств, 
частично за счет помощи бюджета. В текущих условиях нехватки отдельных видов сельскохозяйственной продукции Калужская область имеет преимущества перед другими субъектами в этом отношении ввиду наличия успешной ранее подготовленной базы.

Таблица 1

Показатели социально-экономического развития

\begin{tabular}{|c|c|c|c|c|}
\hline № & Показатель & $\begin{array}{c}\text { Калужская } \\
\text { область }\end{array}$ & $\begin{array}{l}\text { Средний } \\
\text { nо ЦФО }\end{array}$ & $\begin{array}{l}\text { Средний } \\
\text { nо РФ }\end{array}$ \\
\hline 1 & Индекс промышленного производства & 89,7 & 94,0 & 97,0 \\
\hline 2 & $\begin{array}{l}\text { Индекс фиизического объема инвестиций } \\
\text { в основной капитал }\end{array}$ & 73,3 & 95,5 & 89,5 \\
\hline 3 & $\begin{array}{l}\text { Индексы потребительских цен } \\
\text { товары и услуги }\end{array}$ & 9,3 & 110,2 & 109,4 \\
\hline 4 & Безработица & 4,3 & 3,6 & 5,4 \\
\hline 5 & Реальные денежные доходы & 90,8 & 95,0 & 95,6 \\
\hline 6 & Оборот розничной торговЛИ & 90,7 & 91,5 & 91,9 \\
\hline
\end{tabular}

государственной статистики

Вышеописанные тенденции ведут к ухудшению динамики бюджетных показателей, а именно доходной его части, что негативно может отразиться на развитии региона ввиду повышенной нагрузки на бюджет в кризисных условиях.

\section{Анализ бюджетньхх рисков}

К рискам бюджетов регионов следует относить увеличение дефицита бюджета (Киреева, 2013) в результате снижения некоторых видов доходов бюджета. Высока степень непроизводительных расходов, из-за чего снизились источники для создания дохода. Согласно разработанной нами системе рисков бюджетов (Vlasova, 2015; P. 362), в настоящее время можно предположить вероятность существования таких рисков, как снижение поступлений от налога на доходы физических лиц ввиду сокращений работников предприятий (Бочко, 2015) в основном сектора машиностроения, а также от налога на прибыль организаций по причине падения деловой активности. 


\section{Доходы бюджета Калужской области}

В 2014 году, согласно отчетам об исполнении бюджета ${ }^{5}$, наибольший удельный вес в доходах консолидированного бюджета Калужской области составили налоговые доходы - 78,6\%. Среди них наиболее значительное место занимает налог на доходы физических лиц - 32,9\% (17,2 млрд руб.), акцизы ${ }^{6}-15,1 \%$ (7,9 млрд руб.), налог на прибыль организаций - 14,2\% (7,4 млрд руб.) и налог на имущество организаций - 6,7\% (3,5 млрд руб.). Значительный вес имеют безвозмездные поступления, составляющие от общего объема доходов 15,3\% (8 млрд руб.). (рис. 4).

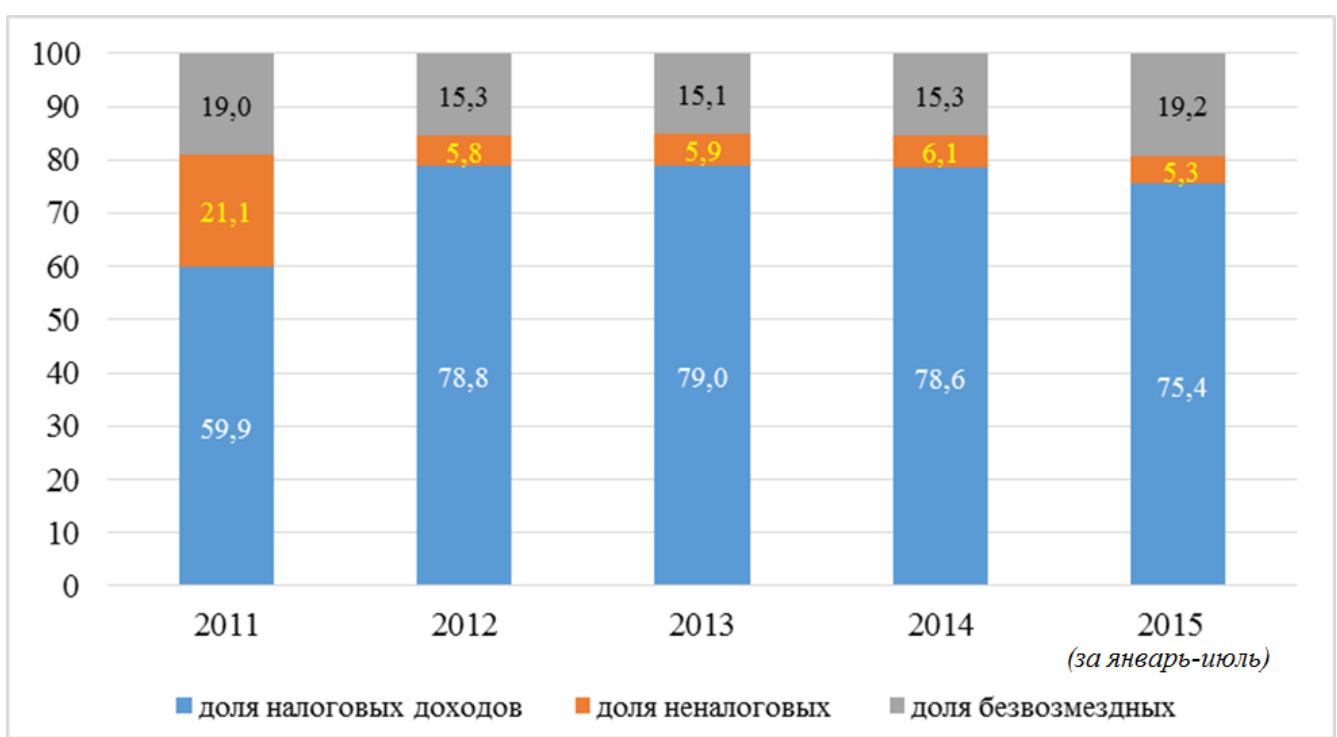

Рисунок 4. Структура доходов Калужской области, \%

Источник: составлено авторами по данным Федерального Казначейства РФ

Общий объем доходов составил 52,2 млрд руб., на 2,1\% больше, чем в 2013 году.

По сравнению с 2013 годом выстроилась следующая динамика: выросли налог на доходы физических лиц - на 6,5\% (на 1,04 млрд руб.), акцизы - на 19,3\% (на 1,28 млрд руб.), налог на имущество физических лиц - на 9,1\%, налоги на совокупный доход - на $8,4 \%$. Резко возросли такие статьи, как «Налог на игорный бизнес», «Задолженность и перерасчеты по отмененным налогам, сборам и иным обязательным платежам» и «Штрафы, санкции, возмещение ущерба» - на 52,3\%, 41,1\%

\footnotetext{
${ }^{5}$ Отчет об исполнении областного бюджета за I полугодие 2015 года (2015; 1 августа) // Официальный портал органов власти Калужской области.

${ }^{6}$ Акцизы по подакцизным товарам.
} 
и 45,5\% соответственно. Однако в абсолютном выражении такое резкое увеличение малозначимо.

Уже в 2014 году существенно снизились поступления от налога на прибыль организаций - на 19,5\% (на 1,8 млрд руб.), от налога на имущество организаций - на 10,4\% (на 0,4 млрд руб.).

В 2015 году продолжили сокращаться поступления от налога на прибыль - за январь-июль на 2,6\%. Есть риск продолжения снижения поступлений от данного налога, связанное с резким сокращением продаж и производства, прежде всего, на автомобильных заводах, расположенных в Калужской области.

Аналогично ситуация может отразиться на доходах от НДФЛ. Несмотря на рост на 6,3\%, при сохранении нестабильной экономической ситуации имеется существенный риск сокращения объема по итогам года или остановки роста показателя. Доля НДФЛ в структуре доходов бюджета уже сократилась.

Положительная динамика поступлений также отмечается от акцизов - на $16,1 \%$, в основном за счет роста сборов от акцизов на автомобильный бензин, на $5,5 \%$ выросли сборы от налогов на совокупный доход, однако это один из самых низких темпов роста по ЦФО, и, учитывая налоговые преференции для МСБ, введенные в 2015 году, поступления от этого налога высокими темпами расти не будут.

В связи с изменениями налогового законодательства, в сфере налогообложения недвижимости на 57,6\% выросли налоги на имущество физических лиц, на 78,9\% - на имущество юридических лиц. Также повысились сборы от транспортного налога на 26,1\%, на поступления от государственной полшины на 76,6\%. Объем задолженности по налогам и сборам сократился на 67\%. Данные изменения несколько изменили структуру налоговых доходов Калужской области (рис. 5).

В целом объем собственных доходов Калужской области в 2015 году растет. За январь-июль 2015 г. он составил порядка 50,3 млрд руб., в то время как за весь 2014 год объем собственных доходов составил 43,3 млрд руб. Рост объема собственных доходов свидетельствует о грамотной бюджетной политике, реализуемой регионом, и позволяет делать выводы о наличии у региона внутренних резервов, которые позволяют сгладить влияние кризисных условий на экономику региона. 

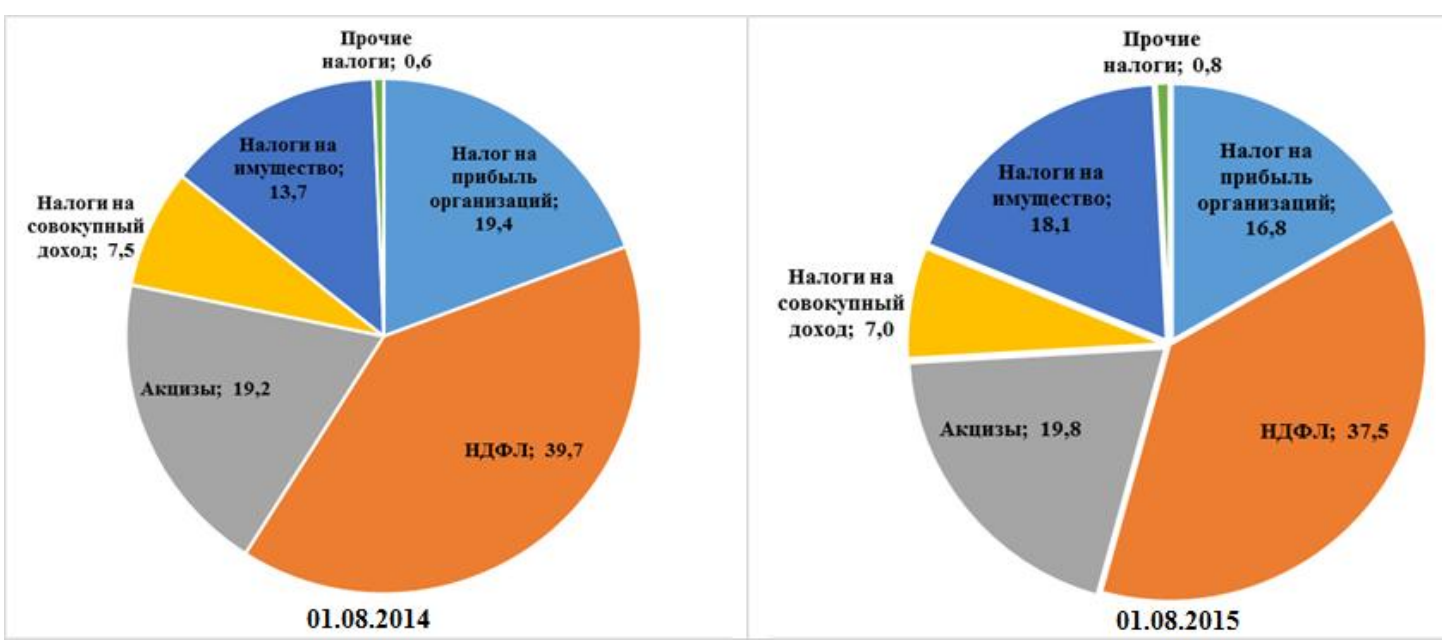

Рисунок 5.Структура налоговых доходов Калужской области за январь-июль, \% Источник: составлено авторами по данным Федерального Казначейства РФ

Объем получаемых субъектом межбюджетных трансфертов на протяжении 3 лет с 2012 года после резкого (на 21\%) сокращения в 2011 году оставался практически на неизменном уровне в 7,7-7,9 млрд руб.

В структуре безвозмездных поступлений постепенно снижается объем дотаций, причем в процентном отношении их доля упала с $26,6 \%$ в 2011 году до 7\% в 2014. В структуре самих дотаций больше всего снизились дотации на выравнивание бюджетной обеспеченности - более чем в 16 раз. Это может быть связано с тем, что Калужская область достигла высокого уровня бюджетной обеспеченности после падения в 2012 году. В 2014 году уровень бюджетной обеспеченности был одинаковым до и после распределения дотаций и составил 0,9447. В 2012 году после распределения дотаций он был равен $0,900^{8}$. Повышение уровня говорит об эффективности и достаточности дотаций для бюджета Калужской области.

С начала 2015 года, в том числе в рамках антикризисной программы, из федерального бюджета было выделено больше средств на предоставление межбюджетных трансфертов для регионов. Так, с января по июль 2015 года Калужская область получила на 56,3\% больше безвозмездных поступлений в сравнении с аналогичным периодом предыдущего года. Однако их структура претерпела значительные изменения. За исследуемый период сократился объем предоставляемых

\footnotetext{
${ }^{7}$ Методика и результаты распределения дотаций на выравнивание бюджетной обеспеченности субъектов Российской Федерации на 2012-2014 годы // Сайт Министерства финансов Российской Федерации.

${ }^{8}$ Там же.
} 
региону дотаций - на 8,9\%, при этом вовсе не выплачивались дотации на выравнивание бюджетной обеспеченности, на 3,3\% снизился объем дотаций бюджетам на поддержку мер по обеспечению сбалансированности бюджетов. Объем субсидий сократился на 47,8\%, в тоже время объем предоставленных субвенций вырос почти на 50\%. Поскольку субвенции по своей сути сильно ограничивают свободу распоряжения поступившими денежными средствами, можно сделать вывод, что федеральный бюджет предполагает таким образом сократить нецелевое использование средств регионами и больше контролировать их действия.

Согласно нашим расчётам, собственные доходы Калужской области тесно зависят (на 73,7\%) от динамики индекса промышленного производства. Это свидетельствует, с одной стороны, о высоком уровне развития производственного сектора в регионе, но, с другой стороны, сигнализирует о необходимости создавать определенную «подушку безопасности» на случай замедления производства, кризиса, снижения потребительского спроса, стагнации экономики. В этом смысле необходима разработка Правительством региона дополнительных мер для нивелирования временных/циклических рисков снижения доходов в будущем.

\section{Расходы бюджета Калужской области}

В 2014 году общая сумма расходов консолидированного бюджета Калужской области составила 58,1 млрд руб., что на 4,8\% больше, чем в 2013 году.

Тем не менее, большая часть расходов, порядка 75\%, производительные, что является благоприятным фактором.

По сравнению с 2013 годом, в 2014 году возросли расходы по следующим статьям: «Обслуживание государственного и муниципального долга» - на 43,4\%, «Здравоохранение» - на 12,2\%, «Национальная экономика» - на 10,9\%, «Культура, кинематография» - на 9,7\%, «Социальная политика» - на 8,1\%, «Национальная оборона» - на 3,9\%, «Общегосударственные вопросы» - на 3,5\%. Весьма неблагоприятной тенденцией за 2014 год явился резкий рост расходов на обслуживание госдолга.

В 2014 году резко снизились расходы на охрану окружающей среды - на 23,6\%, на национальную безопасность и правоохранительную деятельность - на 18,5\%, на физическую культуру и спорт - на $10,1 \%$ и 
на СМИ - на 6,8\%. Снижение расходов на ЖКХ (-9,5\%), учитывая тот факт, что это производительные расходы, может в дальнейшем негативно сказаться на экономике региона и благосостоянии жителей.

В 2015 году ускорился рост расходов консолидированного бюджета Калужской области. В период с января по июль 2015 года рост составил более 10\% по сравнению с аналогичным периодом 2014 года. Наиболее существенно возросли расходы на ЖКХ (47,7\%), национальную безопасность и правоохранительную деятельность (28,7\%), на охрану окружающей среды (25,3\%), СМИ (20,3\%), на здравоохранение и социальную политику (18 и 17,7\% соответственно). В целом социальные расходы увеличились за исследуемый период на $8,5 \%$.

Вышеописанные изменения привели к изменениям в структуре расходов (рис. 6).

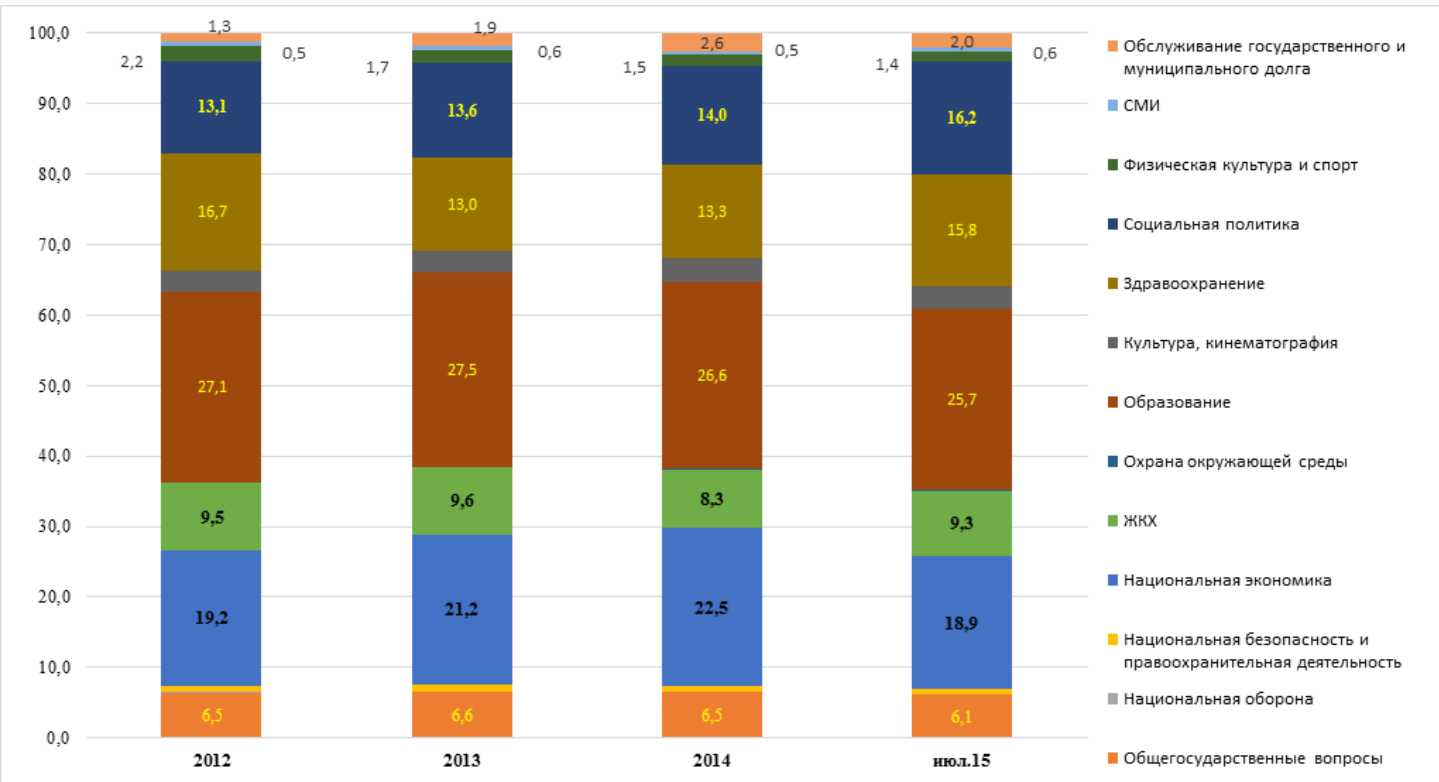

Рисунок 6. Структура расходов консолидированного бюджета Калужской области, \%. Источник: составлено авторами по данным Федерального Казначейства РФ

Расходы региона на общегосударственные вопросы находятся на уровне ниже среднего по ЦФО и Российской Федерации в целом, что является несомненным плюсом бюджетной политики Калужской области. Доля расходов на национальную экономику занимает довольно высокую долю, приближенную к развитым регионам. Отмечаются высокие расходы на ЖКХ, более 9\% от доходов на 01.08.2015, что выше среднего по РФ. 
Следует отметить, что социальные расходы занимают порядка 60\% расходов бюджета региона, это является средним показателем по России в целом и не может нести высоких рисков в краткосрочном периоде для бюджета региона.

\section{Дефицит бюджета и источники его финансирования}

Дефицит консолидированного бюджета Калужской области наблюдается с 2012 года (рис. 7). В 2015 году было запланировано резкое снижение дефицита бюджета с 5,1 млрд руб. до 0,9 млрд руб. Возможно, что данный показатель Калужской области удастся достичь ввиду сокращения дефицита консолидированного бюджета до 0,5 млрд руб. на 01.08.2015 и положительной динамики доходов бюджета.

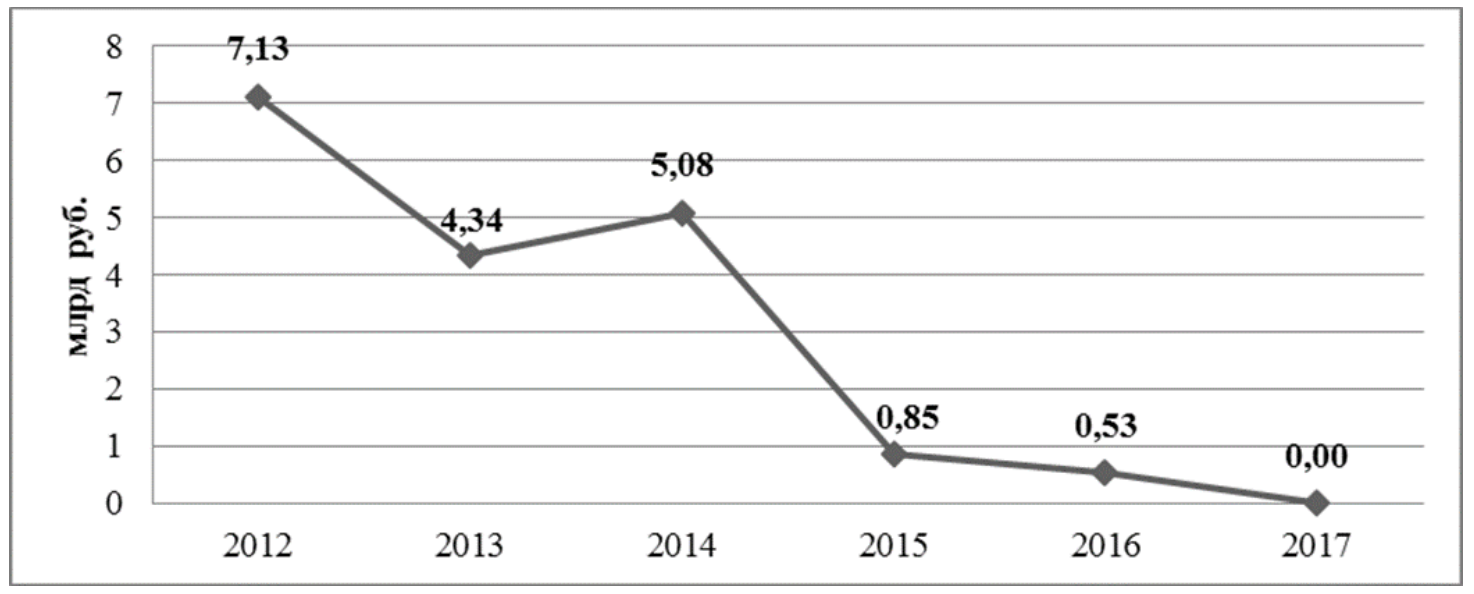

Рисунок 7. Дефицит бюджета 2012-2017 гг.

Источник: рассчитано авторами по данным Федерального Казначейства РФ

Тем не менее, важно обратить внимание на источники покрытия дефицита бюджета.

\section{Государственный долг}

Государственный долг Калужской области за период 2012-2014 гг. демонстрирует устойчивый рост. Отмечались скачки роста объема долга в 2009 и 2010 года, что объясняется последствиями мирового финансового кризиса, а также в 2013 году (на 24,2\%) и в первом квартале 2015 года (на 20,4\%) (рис. 8).

Из общей структуры долга почти 90\% приходится на долг субъекта и лишь оставшиеся $10 \%$ - на местные органы власти. 


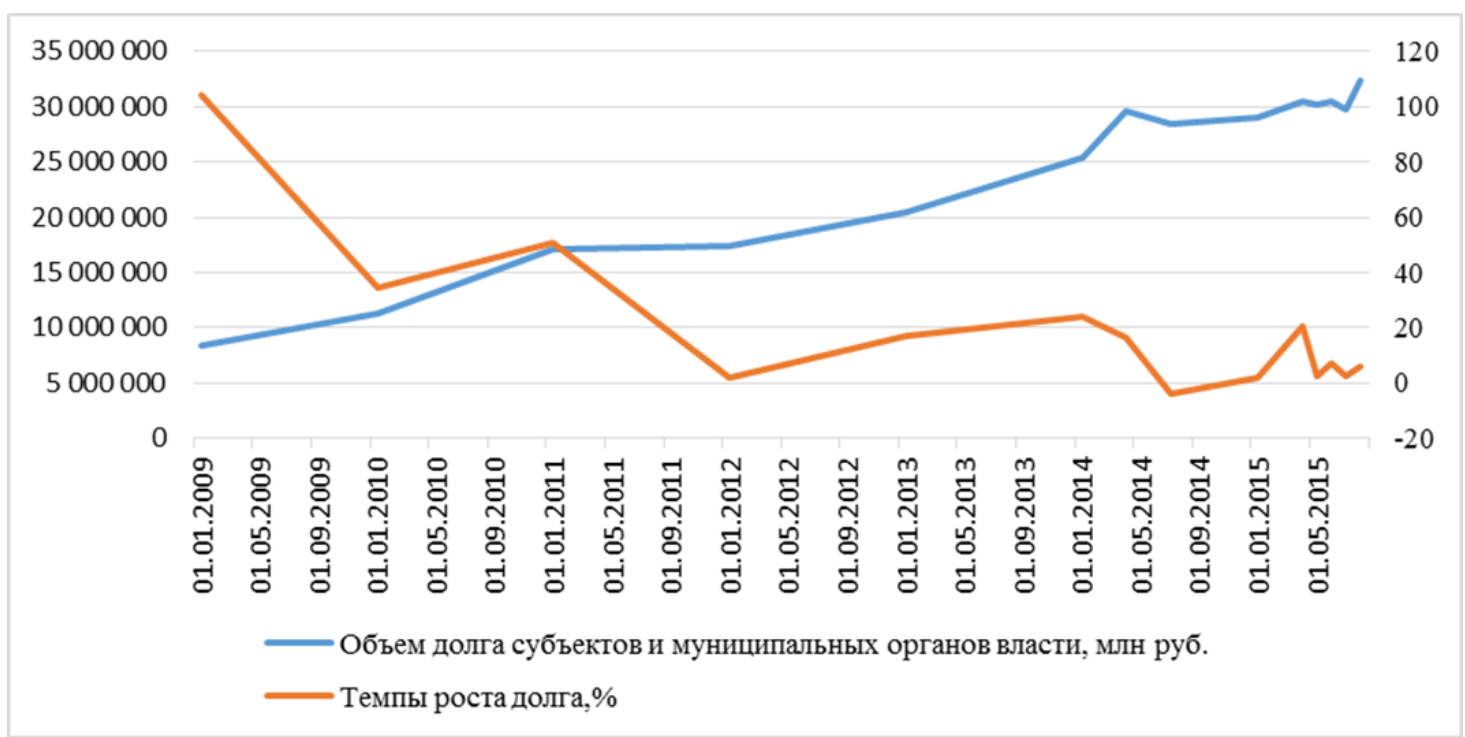

Рисунок 8. Государственный долг Калужской области 2012-2015 гг.

Источник: составлено авторами по данным Министерства Финансов Р $\Phi^{9}$

За первые семь месяцев 2015 года объем долга субъекта и муниципальных образований достиг 32,4 млрд руб., увеличившись с начала 2015 г. года на 11,8\%.

Чрезвычайно высокие темпы роста расходов на обслуживание госдолга в 2013 и 2014 гг. (46,0\% и 43,4\% соответственно) являются крайне негативной тенденцией. Это свидетельствует о неэффективном управлении региона своим долгом, так как расходы на обслуживание государственного долга являются непроизводительными.

Сейчас у региона имеется единственный выпуск процентных документарных амортизационных облигаций на предъявителя на сумму 1,2 млрд руб. Тем не менее, в структуре долга ценные бумаги занимают лишь 4\%. Однако в 2016 года облигации должны быть погашены полностью, что будет являться значительной нагрузкой на бюджет в текущих условиях. Наибольшую долю в структуре долга Калужской области занимают кредиты коммерческих организаций и кредиты бюджета - 36,2 и $40,7 \%$ соответственно. Объем кредитов из федерального бюджета в структуре долга Калужской области за 2015 года возрос на 85\%. А объем кредитов кредитных организаций сократился на 6,8\%, однако после его существенного роста (более чем на

\footnotetext{
${ }^{9}$ Объем государственного долга субъектов Российской Федерации и долга муниципальных образований // Сайт Министерства финансов Российской Федерации.
} 
20\%) в 2014 году следует ожидать возможное увеличение данного показателя по итогам года.

Таким образом, необходимо отметить два негативных момента. Во-первых, долг Калужской области преимущественно имеет среднесрочный характер и очевидно, что часть долга будет реинвестирована, тем самым долговая нагрузка на региональный бюджет не снизится. В средне- и долгосрочном периодах регулярное перекредитование региональных и местных властей под низкие ставки за счет средств федерального бюджета и крупных кредитных организаций не приведет к повышению эффективности использования средств регионом (Солдаткин, 2015), не поспособствует формированию позитивного долгосрочного кредитного рейтинга субъекта (Власова, 2015). Во-вторых, низкая доля ценных бумаг в структуре долга субъекта, свидетельствует не только об отсутствии долгосрочного планирования долга в регионе, но может иметь и более серьезные последствия. Так, экспертами (Криничанский, 2015) доказано, что ВРП региона и темпы роста инвестиций в основной капитал растут более высокими темпами в регионах, которые имеют опыт регулярных заимствований на рынке субфедеральных облигаций, и что в данной категории регионов прослеживается более тесная связь кредитов с инвестициями и выпуском. Тем самым Правительство субъекта должно быть озабочено вопросами развития внутреннего финансового рынка и активно принимать в нем участие.

По итогам нашего исследования, были рассчитаны основные бюджетные показатели (табл. 2), которые отражают некоторое ухудшение ситуации по отдельным параметрам. Тем не менее, значения коэффициентов, кроме коэффициента дотационности, еще не достигли после кризисного периода 2011 года, что свидетельствует о наличии у региона потенциала выдержать настоящие негативные тенденции в экономике, с учетом корректировки некоторых статей расходов (например, на ЖКХ) и долговой политики.

Рейтинговое агентство Fitch подтвердило рейтинги Калужской области: долгосрочные рейтинги дефолта эмитента («РДЭ») в иностранной и национальной валюте на уровне «ВВ» со «Стабильным» прогнозом и краткосрочный РДЭ в иностранной валюте «В». Также подтвержден национальный долгосрочный рейтинг региона на уровне «AA-(rus)» со «Стабильным» прогнозом. 
Таблица 2

Показатели эффективности бюджетной политики региона

\begin{tabular}{|c|l|c|c|c|c|c|}
\hline & 2011 & 2012 & 2013 & 2014 & $2015^{*}$ \\
\hline 1 & $\begin{array}{l}\text { Коэфффициент } \\
\text { бюджетного покрытия }\end{array}$ & 1,07 & 0,94 & 0,92 & 0,90 & 0,99 \\
\hline 2 & $\begin{array}{l}\text { Коэффициент } \\
\text { дотационности }\end{array}$ & 0,23 & 0,18 & 0,18 & 0,18 & 0,24 \\
\hline 3 & $\begin{array}{l}\text { Коэфффициент } \\
\text { дефицита бюджета }\end{array}$ & 0,08 & $-0,08$ & $-0,10$ & $-0,13$ & $-0,02$ \\
\hline 4 & $\begin{array}{l}\text { Коэфффициент } \\
\text { деловой активности }\end{array}$ & 0,26 & 0,07 & 0,07 & 0,07 & 0,07 \\
\hline 5 & $\begin{array}{l}\text { Доходы на душу } \\
\text { населения }\end{array}$ & 471259,98 & 49750,93 & 50878,75 & 51977,63 & 33865,31 \\
\hline 6 & $\begin{array}{l}\text { Коэфффициент } \\
\text { бюджетной } \\
\text { обеспеченности }\end{array}$ & 47769,79 & 53040,30 & 55112,63 & 57790,97 & 34328,64 \\
\hline
\end{tabular}

${ }^{*}$ на 01.08.2015.

Источник: составлено авторами по данным Федерального Казначейства РФ, Минфина РФ

К рискам отнесены:

- риск роста долга;

- риск роста операционных расходов;

- риск, связанный с обязательствами предприятий госсектора.

Последний риск связан с тем, что область использует средства предприятий государственного сектора для финансирования региональных инвестиционных проектов. Данные предприятия привлекают кредиты для этих целей, а правительство области предоставляет субсидии для выплаты основной суммы долга. Позитивным фактором является долгосрочная структура обязательств компаний госсектора - до 2022 г.

\section{Политика Калужской области в сфере укрепления доходного потенциала}

Калужская область занимает второе место в Национальном рейтинге состояния инвестиционного климата в субъектах $Р \Phi^{10}$, по трем параметрам (регуляторная среда, институты для бизнеса и поддержка малого предпринимательства) ей выставлен высший балл, по параметру «Инфраструктура и ресурсы» - уровень С (оценки выставляются от А до E).

\footnotetext{
${ }^{10}$ Агентство стратегических инициатив. (2015). Национальный рейтинг состояния инвестиционного климата в субъектах РФ. Результаты 2015. Режим доступа: http://www.investinregions.ru/u/section_file/106/2015_ru.pdf
} 
Субъект занимает первое место по параметру «Среднее время регистрации предприятий», срок составляет 10,08 дня ${ }^{11}$. Такой успешный показатель был достигнут благодаря следующим действиям:

- внедрению контроля за соблюдением сроков регистрации инспекциями ФНС;

- проведению анализа нагрузки на сотрудников ФНС, по итогам которого осуществлено перераспределение количества сотрудников в инспекциях области;

- использованию инструментов мотивации сотрудников;

- проведению мероприятий по улучшению информационной осведомленности заявителей;

- реализации возможности подачи пакета документов на регистрацию предприятий в электронной форме.

Данные практики достаточно легко реализуемы и не требуют значительных ресурсных затрат, поэтому опыт Калужской области в этом направлении можно было бы успешно перенести на другие регионы.

По показателю «Получение разрешений на строительство» Калужская область также в первых строчках рейтинга. Предпринятые действия:

- разработка методических указаний к регламенту при выдаче разрешения на строительство и регламенту подготовки градостроительной документации;

- осуществление приоритизации проектов по степени значимости для области;

- переработка процедуры выдачи технических условий;

- курирование представителем Агентства регионального развития Калужской области крупных инвестиционных проектов или наиболее приоритетных проектов;

- двустороннее участие застройщиков и администрации муниципальных образований в процессе выдачи разрешения на строительство;

- оптимизация этапа подготовки и выдачи ГПЗУ;

\footnotetext{
${ }^{11}$ Агентство стратегических инициатив. (2014). Лучшие управленческие практики: Итоги пилотного апробирования Национального рейтинга состояния инвестиционного климата в субъектах Российской федерации. Режим доступа: http://www.investinregions.ru/u/section_file/113/practices_ru.pdf
} 
- взятие администрацией муниципального образования на себя некоторых подготовительных процедур при подготовке участков земли для аукциона;

- параллельное проведение этапа государственной экспертизы с этапом разработки проектной документации.

По показателю «региональная организация по привлечению инвестиций и работе с инвесторами» Калужская область заняла второе место. В ней создано две организации для осуществления данной деятельности: ГАУ «Агентство регионального развития Калужской области» и ОАО «Корпорация развития Калужской области». Основными подходами к работе с инвесторами является размещение производства в индустриальных парках и ОЭЗ, низкие риски инвестирования, налоговые льготы и административная поддержка со стороны органов власти.

По показателю «Налоговые льготы в регионе» субъект занял первое место, предприняв следующие меры:

- разработка приоритетных направлений для инвестиционной деятельности и разработка системы налоговых льгот с учетом этих приоритетов;

- введение по налогу на прибыль, на имущество;

- отдельная система налоговых льгот на территории ОЭЗ «Людиново».

По показателю «Государственные гарантии и государственные гарантийные фонды» Калужская область также лидирует.

В целом, можно выделить главную причину успеха Калужской области - это плодотворное взаимодействие государства и бизнеса. Также нужно отметить высокую степень информатизации. Калужская область имеет большое количество порталов, посвященных инвестированию в область, с удобным интерфейсом и полнотой представленных данных.

Другие регионы могут воспользоваться опытом Калужской области и предпринять следующие меры:

- определить приоритеты инвестирования;

- ввести налоговые льготы для инвесторов, в особенности работающих в приоритетных направлениях;

- максимально упростить процедуру регистрации и получения необходимых разрешений; ввести электронный документооборот;

- создать систему индустриальных парков и особых экономических зон с прозрачными условиями инвестирования;

- развивать государственно-частное партнерство и привлекать бизнес к разработке законодательных актов, касающихся предпринимательства в области. 
Доходный потенциал регионов сейчас находится в шатком положении, поэтому субъектам следует мобилизовать все свои силы на его укрепление. В свете риска снижения доходов от налоговых поступлений, особенно от налога на прибыль и НДФЛ, которые, в отличие от НДС и НДПИ, отличаются высокой цикличностью (Ильин, Поварова, 2014), возможной мерой поддержки доходов территориальных бюджетов может стать передача поступлений от налога на прибыль в полном объеме на региональный уровень, тем более что в формировании доходов федерального бюджета доля этого платежа не превышает 3\%. Увеличить поступления от НДФЛ помогло бы введение прогрессивной шкалы налога. По оценкам экспертов ${ }^{12}$, эффект от введения прогрессивной шкалы для территориальных бюджетов будет более 2 трлн руб.

Также требуется максимально развивать малое и среднее предпринимательство, которое обеспечивало бы население необходимыми продуктами и услугами и создавало рабочие места, обеспечивало диверсификацию экономики. Для этого необходимо налаживать контакт между государством и частным сектором, максимально облегчать ведение бизнеса путем введения налоговых льгот и ускорения и упрощения бюрократических процедур. Несмотря на то, что потребительская направленность МСП делает его более уязвимым в кризисных ситуациях, его гибкость и высокая приспосабливаемость способны снижать негативные последствия неблагоприятной внешней экономической конъюнктуры (Толмачев, Ульянова, Плинер, 2015), что сейчас очень важно в вопросах импортозамещения продуктов питания.

Развитие государственно-частного партнерства, уже зарекомендовавшее себя в России, также оказало бы огромное положительное влияние на улучшение инвестиционного климата российских регионов (Чалова, Трегубова, 2014) и, как следствие, привлечение инвестиций и рост производства. Правительство Калужской области успешно создает с помощью ГЧП индустриальные парки на своей территории на смешанной и контрактной основах. Тем не менее, в условиях неопределённости для привлечения инвесторов необходимо дальнейшее совершенствование механизмов ГЧП, особенно в сфере финансирования и налогообложения (Федорова, 2014; Абрамова, 2015).

Необходимо корректировать бюджетную политику, снижая долю непроизводительных расходов и наращивая производительные (национальную экономику, ЖКХ, образование и т.д.). В

\footnotetext{
12 Яшина, Г. (2010, 20 апреля). Прогрессивное налогообложение: «за» и «против» // Федеральное интернет-издание «Капитал страны».
} 
непроизводительных расходах значительную долю занимает обслуживание государственного и муниципального долга, соответственно, региону следует добиваться снижения таких расходов.

\section{Заключение}

В целом, для улучшения доходного потенциала регионов необходимо осуществить целый комплекс мер, реализация которых требует ресурсов и времени, но в будущем это будет иметь мощный положительный эффект для всей экономики страны.

\section{ИСТОЧнИКИ:}

Абрамова, А.И. (2015). Государственно-частное партнерство в России. В книге Двадцать восьмые Международные Плехановские чтения (Том 2; С. 150-153). М.: РЭУ им. Г. В. Плеханова.

Бочко, В.С. (2015). Ускоряющие и сдерживающие факторы скоординированного и сбалансированного развития регионов. Экономика региона, 1, 39-52.

Валентей, С.Д., Бахтизин, А.Р., Бухвальд, Е.М., Кольчугина, А.В. (2014). Тренды развития российских регионов. Экономика региона, 3, 9-22.

Власова, Ю.А. (2015). Состояние и перспективы развития долговых инструментов субъектов Российской Федерации. В книге Проблемы социально-экономического развития регионов. Международная научно-практическая конференция (С. 2022). Уфа: Аэтерна.

Ильин, В.А., Поварова, А.И. (2014). Проблемы регионального развития как отражение эффективности государственного управления. Экономика региона, 3, 48-63.

Киреева, Е.В. (2013). Проблемы финансирования бюджетного дефицита в условиях нестабильного рынка. Вестник РГГУ. Серия: Экономика. Управление. Право, 15, 179-184.

Криничанский, К.В. (2015). Финансовые рынки: анализ влияния на социальноэкономические процессы в российских регионах. Региональная экономика: теория и практика, 4, 13-27.

Репова, М.Л., Сазанова, Е.В., Лобанова, Ю.С. (2014). Инструментарий социальноэкономического мониторинга регионов для целей управления. Финансовая аналитика: проблемы и решения, 13, 44-53.

Солдаткин, С.Н. (2015). Эффективность региональной долговой политики через призму инвестиционной активности. Региональная экономика: теория и практика, 30, 46-57.

Толмачев, Д.Е., Ульянова, Е.А., Плинер, Л.М. (2015). Развитие малого и среднего бизнеса в регионе: формирование приоритетных направлений на примере свердловской области. Экономика региона, 1, 115-131.

Федорова, Е.А. (2014). Факторы, влияющие на приток иностранных инвестиций в регионы. Региональная экономика: теория и практика, 43, 51-62. 
Чалова, А.Ю., Трегубова, Д.Д. (2014). Роль государственно-частного партнерства в социально-экономическом развитии регионов Российской Федерации. В книге Проблемы социально-экономического развития регионов. Сборник статей Международной научно-практической конференции (С. 117-121). Уфа: Башкирский государственный университет.

Vlasova, Ju. (2015). Budget Risks of Russian Federation Regions, Determination and the Application in the Budget Process. Mediterranean Journal of Social Sciences, 6(4 S4), 362-368. doi: 10.5901/mjss.2015.v6n4s4p362

Yulia A. Vlasova, Candidate of Science, Economics, Senior teacher of the Chair of Finance and Prices, Plekhanov Russian University of Economics

Anastasia I. Abramova, a 4-year student of the Department of Finance, Plekhanov Russian University of Economics

\section{The problems of strengthening profitable potential of regional budgets in Russia on the example of the Kaluga Region}

ABSTRACT:

The article is devoted to researching income formation features of Russian regions, on the example of the Kaluga region. The subject of the research is financial, social and economic position of the Kaluga region.

The paper aimed at identification of possible budgetary, social and economic risks of the subject influencing the profitable potential of the region, and also identification of additional allowances in order to increase the budget's revenue of the subject.

The paper reveals the most actual issues of expenses covering and debt management, gives the assessment of budget capacity of the region made by means of statistic analysis, and also by means of calculation of efficiency indices in the budgetary policy.

Profitable capacity of the region in respect of tax income as the main source of regional budget formation is researched. Changes in budget's revenue are assessed. The debt load of the subject and risks connected with the change in amount and structure of a debt, as well as the methods of state debt management are researched.

The authors offered recommendations aimed at increase of profitable capacity of the region, considering its features and present economic situation which could be used in development of the budget policy of the subject.

Profitable capacity of regions is in a tight position, therefore, subjects should direct all the forces to strengthen it. In the presence of the risk of reduction in income from tax revenues it is required to develop small and average business that would provide the population with necessary products and services and create new vacancies. For this purpose it is necessary to implement public and private partnership more actively, as well as to facilitate business effectively by implementing tax privileges and accelerating and simplifying bureaucratic procedures. It is also necessary to reduce a share of non-productive costs and increase productive ones that will lead to the increase in efficiency of the regional budget policy. A complex resolution of the problem at the present time will lead to a long-time powerful positive effect for the whole economy of the region.

KEYWORDS: profitable potential, budget of the subject, budget risks, tax income 